\section{Majin: A Miniature DNA Element Associated with the Genomes of Pome Fruit Trees}

\author{
Y. Wakasa, R. Ishikawa, M. Niizeki, and T. Harada ${ }^{1}$ \\ Faculty of Agriculture and Life Science, Hirosaki University, Bunkyo-cho, \\ Hirosaki 036-8561, Japan

\section{Gene Research Center, Hirosaki University, Bunkyo-cho, Hirosaki 036-8561, Japan} \\ S. Jin, M. Senda, and S. Akada
}

Additional index words. apple, Malus $\times$ domestica, Maloideae, interspersed element, DNA fingerprinting, DNA marker

\begin{abstract}
Sequencing of the sequence tagged site-DNA marker fragments linked to the fruit skin-color gene in apple revealed two fragments containing insertions that are associated with yellow skin color, and are alleles of the red skin gene (Rf). One fragment resulted from the insertion of a 76-bp inverted repeat, whereas the $163 \mathrm{bp}$ in the other fragment was characterized as a mobile element because of the presence of target site duplication. A database search found this latter element in the 5' flanking regions or intron of six apple genes. DNA blot analysis revealed that the element is highly reiterated, with a copy number of between 5000-6000 in the genome of Maloideae (pome) fruit trees. We named this element Majin. Inter-transposon amplified polymorphism using primers from this element resulted in polymorphic bands among apple cultivars.
\end{abstract}

Through a combination of mutant analysis, characterization of DNA polymorphisms within populations, and computer-based surveys, some highly repetitive transposable elements have been found in many eukaryotic genomes. Transposable elements have been divided into two main classes according to their transposition intermediate (Flavell et al., 1994). Class 1 elements include retroposons with a long terminal repeat (LTR) such as Tyl/Copia-like and Ty3/Gypsy-like elements, as well as no-LTR retroposons. Plant genomes contain high copy numbers of these retroelements (Mao et al., 2000). The Class 2 elements transpose via a DNA intermediate and usually have terminal inverted repeats. They consist of autonomous and nonautonomous members such as AC/DS and Mutator (Federoff, 1989). Miniature inverted-repeat transposable elements (MITEs) have similarities in both terminal inverted-repeats (TIRs) sequence and target site duplication (TSD) to those of autonomous class 2 transposons. Therefore, it has been hypothesized that MITEs represent nonautonomous forms of DNA-based transposable elements (Wessler, 1998). The abundance of MITEs in plant genomes has been reported (Bureau and Wessler, 1992, 1994; Casacuberta et al., 1998; Mao et al., 2000;

Received for publication 16 Nov. 2001. Accepted for publication 27 Mar. 2002. We gratefully acknowledge Geza Hrazdina and Susan Brown for their critical reading of this manuscript. Part of this work was funded by the Aomori Green Bio Center.

${ }^{1}$ To whom reprint requests should be addressed.
Pozueta-Romero et al., 1996). More recently, a putative autonomous element of tourist-like MITEs in the maize genome was discovered (Zhang et al., 2001).

Other miniature elements that are not in accordance with the characters of MITEs have also been found (Charrier et al., 1999; Song et al., 1998). These elements appear to represent a new class of miniature transposable elements. Through sequencing of the sequence tagged site-DNA (STS-DNA) marker fragments linked to apple fruit skin color, we have identified a highly reiterated miniature element in the genome of apple and related plant species. We report on the characteristics of this sequence that we named Majin (Malus element identified by Jin).

\section{Materials and Methods}

Plant material. The following plants were used in this study: cultivated apple (Malus $\times$ domestica Borkh. cvs. Fuji, Golden Delicious, Jonathan, Narihokoh, Hirosaki Fuji, Indo), wild apple species (M. prunifolia Rehd., M. hupehensis Rehd., M. pumila Mill.), pear (Pyrus communis L.), Japanese pear (Pyrus pyrifolia Nakai), quince (Chaenomeles lagenaria Koidz., Pseudocydonia sinensis Schneid., Cydonia oblonga Mill.), rowan (Sorbus commixta Hedl.), spiraea (Spiraea thunbergii Sieb., Spiraea cantoniensis Lour.), and cherry (Prunus avium L.). Young expanding leaves of these plants, obtained at the experimental farms of Hirosaki Univ. (Japan), were used for DNA extraction.

DNA extraction. Genomic DNA was isolated from leaves by the method of Varada- rajan and Prakash (1991) and purified by the ethidium bromide-CsCl method of Sambrook et al. (1989).

Sequencing. By using the PCR primers described by Cheng et al. (1996), three DNA markers (A1, a1, and a2) linked to skin-color were amplified from 'Jonathan', 'Narihokoh', and 'Golden Delicious', respectively. 'Jonathan' and 'Golden Delicious' are chance seedlings and 'Narihokoh' is a cross between 'Golden Delicious' and 'Fuji'. Each amplified fragment was subsequently cloned into the pBluescript ${ }^{\circledR}$ IISK(-) phagemid vector (Stratagene, La Jolla, Calif.). Both strands were sequenced using an automated sequencer (LICOR, Lincoln, Neb.) with IRD-labeled M13 forward and reverse primers.

Slot and DNA gel blot hybridization. Majin DNA (153 bp) was amplified by PCR from the cloned a2 fragment using the primers A (5'-GGGAACTTTAACGAAAAGAAGC$3^{\prime}$ ) and B (5'-GGAAAACTAGTGA AAAT GGCTTG-3'). Serial dilutions corresponding to $10^{3}-10^{5}$ copies per genome were slot blotted, along with $50 \mathrm{ng}$ of genomic DNA extracted from young leaves of 'Golden Delicious' apple, onto a membrane (Hybond N+, Amersham). In this calibration for copy number, $750 \mathrm{Mbp}$ per 1C was used for the DNA content of apple (Arumuganathan and Earle, 1991). For gelblot analyses, one $\mu \mathrm{g}$ of genomic DNA extracted from young leaves was digested with HindIII, separated by agarose gel electrophoresis and transferred to the membrane. For both blots, Majin probe DNA was labeled with ${ }^{32} \mathrm{P}-\mathrm{dCTP}$ using the Prime-It II random primer labeling Kit (Stratagene). Membranes were hybridized with the labeled probe at $65{ }^{\circ} \mathrm{C}$ for $15 \mathrm{~h}$ in hybridization buffer ( $10 \mathrm{~mm}$ tris- $\mathrm{HCl}, \mathrm{pH} 7.5$, 1 mM EDTA, $6 \times$ SSC, $5 \times$ Denhardt's solution, $0.2 \mathrm{mg} \cdot \mathrm{mL}^{-1}$ salmon sperm DNA, $20 \mathrm{~mm}$ sodium phosphate buffer, and $1 \%$ SDS). The membranes were washed with $2 \times \mathrm{SSC} / 0.1 \%$ $(\mathrm{w} / \mathrm{v}) \mathrm{SDS}$ at room temperature for $30 \mathrm{~min}$ and $0.2 \times \mathrm{SSC} / 0.1 \%(\mathrm{w} / \mathrm{v}) \mathrm{SDS}$ at $65^{\circ} \mathrm{C}$ twice for 15 min and then autoradiographed at $-80^{\circ} \mathrm{C}$ with Kodak X-ray film and an intensifying screen. Scanning densitometry of slot blot autoradiograms was performed using a densitograph of ATTO (AE-6920M-05, Tokyo).

Inter-transposon amplified polymorphism (ITAP). Primers A or B as inward primers and $\mathrm{C}$ or D (complementary sequences of $\mathrm{A}$ and $\mathrm{B}$, respectively) as outward primers were used for ITAP PCR. A total volume of $25 \mu \mathrm{L}$ reaction mixture contained $100 \mathrm{ng}$ genomic DNA, $1 \times$ PCR buffer (Applied Biosystems, Foster City, Calif.), $2.5 \mathrm{~mm} \mathrm{MgCl}_{2} 0.5 \mu \mathrm{M}$ primer, $200 \mu \mathrm{m} \mathrm{dNTP}$, and $1 \mathrm{U}$ of AmpliTaq Gold DNA polymerase (Applied Biosystems). PCR was carried out in a TaKaRa PCR Thermal Cycler MP (Takara Shuzo, Tokyo). The PCR cycling parameters consisted of a 10-min denaturation at $95^{\circ} \mathrm{C}$, followed by 40 cycles of $1 \mathrm{~min}$ at 94 ${ }^{\circ} \mathrm{C}, 2 \mathrm{~min}$ at $52{ }^{\circ} \mathrm{C}, 3 \mathrm{~min}$ at $72{ }^{\circ} \mathrm{C}$, followed by a final 9 -min extension at $72^{\circ} \mathrm{C}$. Amplified products were electrophoresed on $2 \%$ agarose gels and visualized by ethidium bromide staining. DNA size markers ( $\lambda \mathrm{DNA} /$ StyI and $\phi X 174 / H a e I I I$ digests) were purchased from Nippon Gene (Tokyo). 


\section{Results}

Detection of Majin. By using the universal primers designed by Cheng et al. (1996) and the resulting A1, a1, and a 2 markers, we identified six genotypes arising from combinations of the A1, a1, and a 2 markers in selected apple cultivars. The marker genotypes correlated with the skin-color phenotypes, with marker A1 cosegregating with red skin color and a1 and a2 associated with yellow skin color (Cheng et al., 1996). To investigate the molecular basis of this polymorphism, we sequenced these fragments. Each DNA marker fragment was cloned from its homozygous cultivar (A1 from 'Jonathan', a1 from 'Narihokoh', and a2 from 'Golden Delicious'). The sequence information indicated that the a1 (GenBank Accession No. AB073703) and a2 (GenBank Accession No. AB073704) fragments were virtually identical to A1 (GenBank Accession No. AB073702) except for their respective insertions (Fig. 1A). Sequence data revealed that the $76 \mathrm{bp}$ a1 insertion was an inverted repeat, while the 163 bp insertion in a 2 contained a duplication of a 10-bp target site (Fig. 1B). When the a2 insert was used in a computer-based sequence similarity search, six homologous sequences in the $5^{\prime}$ noncoding regions or intron of six previously sequenced apple genes were identi- fied (Fig. 2). Although the sequence in $M d P I$ had a 28-bp deletion, the remaining region showed high homology to the a 2 insertion. Because of the lack of information about the insert/deletion alleles of these six homologous loci, we are unable to determine whether the flanking sequences of the homologues are duplication products. However, their borders were composed mainly of AT. We named this 153 bp of a 2 insertion sequence Majin (Malus element identified by Jin).

Copynumberand distribution of Majin. The approximate copy number of Majin in apple genomic DNA was determined by slot blot hybridization (Fig. 3). Using high stringency washes, densitometer measurements showed $\approx 6000$ copies per haploid genome. Majin was also used as a probe for DNA gel blots to determine the distribution of this element in other plant species. A positive signal was observed in the genomes of domestic apple cultivars (Fuji), wild apple species, pears, quince species, and rowan. No signal was detected in rice (Oryza sativa), soybean [Glycine max (L.) Merrill], spiraea, or cherry (Fig. 4). Although similar signal intensities were observed among apples, pears, and two quinces, about half of and twice the intensity were obtained from Chaenomeles lagenaria, while Sorbus commixta, respectively.
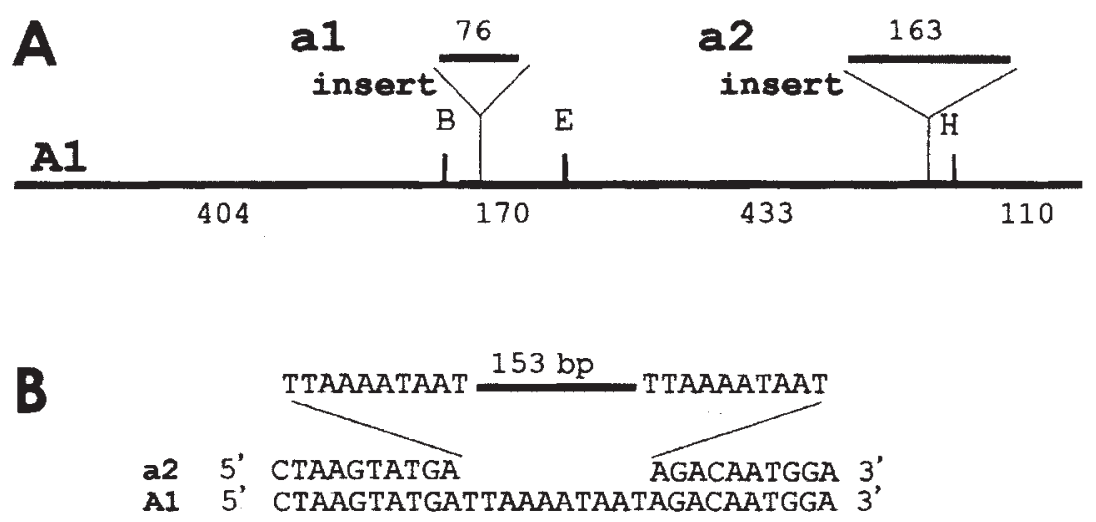

Fig. 1. (A) Schematic representation of the characterization of STS-DNA markers linked to apple fruit skin color. Marker A1 comprises a 1117-bp sequence. Markers a1 (1193 bp) and a2 (1280 bp) each have insertions in $\mathrm{A} 1$ at the positions indicated. Size of each restriction fragment and the restriction site are indicated. $\mathrm{H}=$ HindIII, E = EcoRI, B = BamHI. (B) Sequences flanking the a2 insertion site.

ITAP. Because MITEs are highly repetitive and present in both orientations in the genome, a single primer (e.g., A or B) can amplify PCR products from elements sufficiently close to one another and in the correct orientation (Kalender et al., 1999). The dispersion, ubiquity and prevalence of Majin in the genomes of the pome fruits provide an excellent opportunity for the development of marker systems. To investigate this possibility, inward-facing PCR primers for the $5^{\prime}$ and $3^{\prime}$ ends (Fig. 2, primers $A$ and $B$ ) were used to amplify DNA from five apple cultivars to determine whether these ITAP markers were sufficiently polymorphic. The ITAP bands were generated by amplification using either primer A or B (Fig. 5). Although the amplified patterns were identical between a cultivar and its sport (lanes 1 and 2, Fig. 5 ), each cultivar produced a different banding pattern. Two outward-facing primers corresponding to respective complementary sequences of primer A and B (Fig. 2, primer $\mathrm{C}$ and D) designed for both ends of Majin also produced ITAP (data not shown). PCR amplification using both outward primers or outward and inward primers increased the number of amplified bands (data not shown). However, some combinations resulted in unsatisfactory resolution of the bands for determination of polymorphism because specific bands were amplified excessively.

\section{Discussion}

MITEs are characterized by their small size (between 110 and $500 \mathrm{bp}$ ), their A+T richness ( $>60 \%$ ), the absence of coding regions, strong target site preference for a 2 - to 4-bp sequence (TA, TAA, TTAA), the presence of TIRs, and high reiteration (Bureau et al., 1996; Wessler et al., 1995). Although the Majin of MdRfa2 has a 10-bp target site duplication, it is not clear whether the border sequences of other Majin elements also contain the duplication. Furthermore, the TIRs observed in MITEs are imperfect in the Majin. From these characteristics, Majin elements closely resemble, if anything, Snap, Crackle, and Pop in rice (Song et al., 1998). The classification of the Majin element requires further investigation.

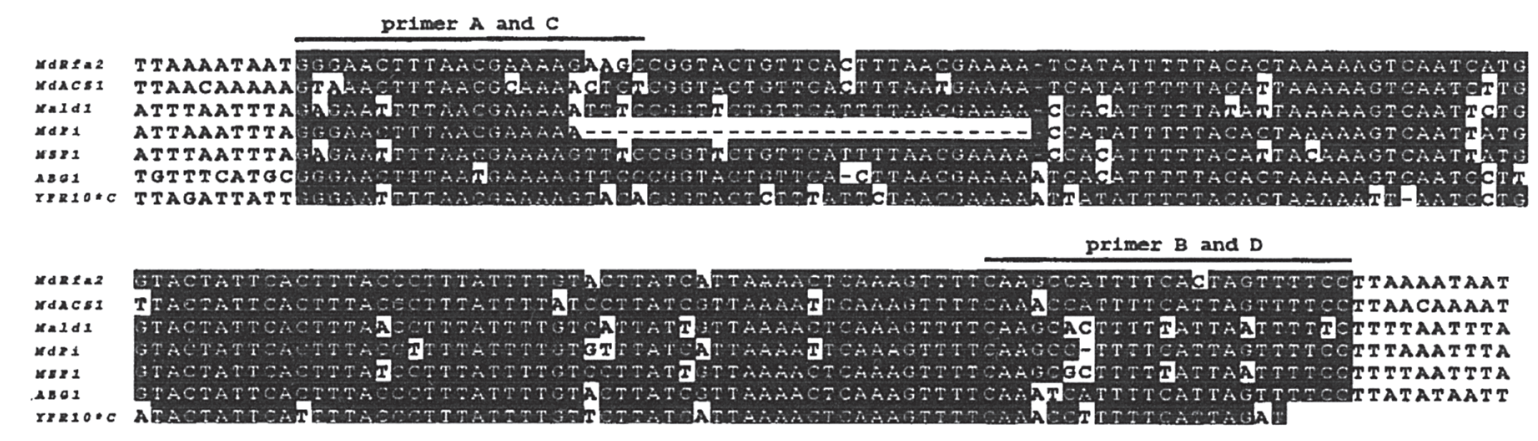

Fig. 2. Sequence alignment of Majin members of a2 and six apple genes from GenBank. The 10 bases at each end indicate the flanking regions of each Majin. Conserved nucleotides are indicated by white letters on a black background. Primers used in this study are shown. GenBank accession numbers and coordinates are: MdRfa2, AB073704, 869-1041; MdACS1, U89156, 596-768; Mald1, AF020542, 228-400; MdPi, AJ291491, 1515-1657; MsPI, AF350245, 228-400; $A B G 1, \mathrm{~A} 84614,1307-1134 ;$ YPR10*C, AY026910, 159-1. 
A positive Majin hybridization signal was obtained on DNA gel blots of Malus, pears, quinces, and rowan. All of these genera belong to the Maloideae, one of the four subfamilies of the Rosaceae (Chapbell et al., 1995). No signal was detected in cherry and two spiraea samples, which belong in the Amygdaloidae and Spireoideae, respectively. These results suggest that Majin is a sequence specific to the
Maloideae. The Maloideae, which include several commercially important fruit crops (Westwood, 1993), are thought to have originated as allopolyploids from Amygdaloideae and Spiraeoideae ancestors (Sax, 1931; Stebbins, 1950; Challice and Kovanda, 1981; Phipps et al., 1991). Thus, there is particular interest in whether Majin is present in subfamilies suspected to be ancestors of the Maloideae.

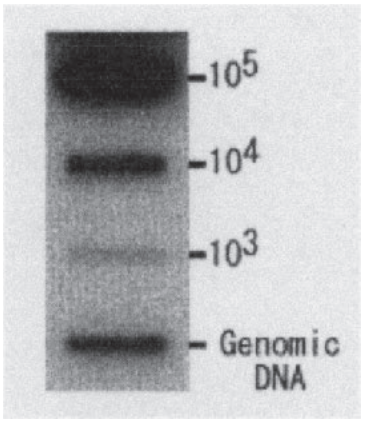

Fig. 3. Copy number of Majin in the apple genome. Genomic DNA from the apple cultivar 'Golden Delicious' and Majin (MdRfa2, PCR product), representing from $10^{3}$ to $10^{5}$ copies relative to the amount of the genome, were diluted serially and transferred to a nylon membrane, then probed with Majin.

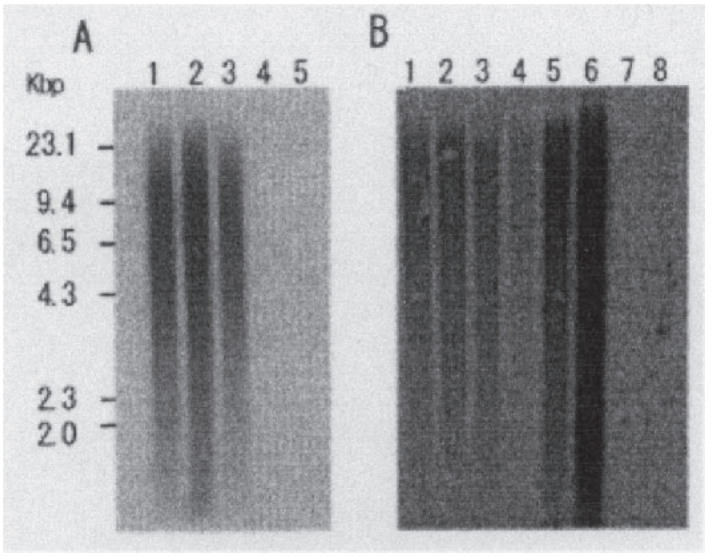

Fig. 4. Species distribution of Majin. One $\mu$ g of HindIII-digested genomic DNA was electrophoresed in a $0.8 \%$ agarose gel, transferred to a nylon membrane, and probed with Majin. (A) Lane $1=$ M. domestica $\mathrm{cv}$. Fuji, $2=$ M. pumila, $3=$ M. prunifolia, $4=$ Oryza sativa $\mathrm{cv}$. Nipponbare, $5=$ Glycine max $\mathrm{cv}$. Williams. (B) 1 = Pyrus communis, $2=$ Pyrus pyrifolia, $3=$ Pseudocydonia sinensis, $4=$ Chaenomeles lagenaria, $5=$ Cydonia oblonga, $6=$ Sorbus commits, $7=$ Spiraea thunbergii, $8=$ Spiraea cantoniensis . Data not presented for M. hupehensis, Pyrus communis (positive signal), and Prunus avium (negative signal). Marker DNA fragment sizes are indicated to the left of the gel in kbp.

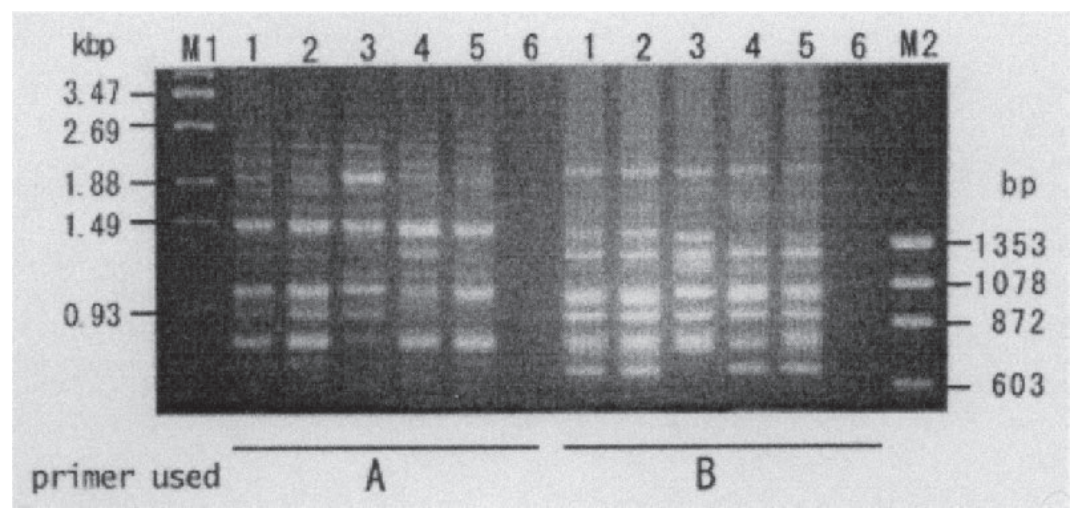

Fig. 5. Banding patterns generated by ITAP from apple cultivars. An agarose gel showing PCR products generated with primer A or B (Fig. 2). Lane M1 = DNA size marker $\lambda$ DNA/StyI, $1=$ Fuji, $2=$ Hirosaki Fuji (a sport of Fuji), 3 = Golden Delicious, 4 = Jonathan, 5 = Indo, 6 = negative control (rice DNA), M2 = DNA size maker $\phi X 174 /$ Hae III.

Although a high reiteration of Majin was revealed in the Maloideae, a computer search found only six apple genes harboring Majin. However, there are very few deposited sequences from the Maloideae, especially from flanking regions where most MITEs have been identified (Wessler et al., 1995). Many additional Majin elements will be reported as sequence records increase. Pome fruit trees frequently produce bud sport mutations that have very interesting morphological traits (Fisher, 1970; Lapins, 1969), including variations in intensity of fruit color (Bishop, 1959). Accessing these mutated loci using the highly reiterated Majin elements will contribute valuable information which can be used for both fundamental and applied genetic problems.

\section{Literature Cited}

Arumuganathan, K. and E.D. Earle. 1991. Nuclear DNA content of some important plant species. Plant Mol. Biol. Rpt. 9:208-218.

Bishop, C.J. 1959. Radiation-induced fruit colour mutations in apple. Can. J. Gen. Cyt. 1: 118-123.

Bureau, T.E., and S.R. Wessler. 1992. Tourist: A large family of small inverted repeat elements frequently associated with maize genes. Plant Cell 4:1283-1294.

Bureau, T.E., and S.R. Wessler. 1994. Stowaway: A new family of inverted repeat elements associated with the genes of both monocotyledonous and dicotyledonous plants. Plant Cell 6:907-916.

Bureau, T.E., P.C. Ronald, and S.R. Wessler. 1996. A computer-based systematic survey reveals the predominance of small inverted-repeat elements in wild-type rice genes. Proc. Natl. Acad. Sci. USA 93: 8524-8529.

Casacuberta,E., J.M. Casacuberta,P.Puigdomenech, and A. Monfort. 1998. Presence of miniature inverted-repeat transposable elements (MITEs) in the genome of Arabidopsis thaliana: Characterisation of the Emigrant family of elements. Plant J. 16:79-85.

Challice, J.S. and M. Kovanda. 1981. Chemotaxonomic studies in the family Rosaceae and the evolutionary origins of the subfamily Maloideae. Preslia 53:289-304.

Chapbell, C.S., M.J. Donoghue, B.G. Baldwin, and M.F. Wojciechowski. 1995. Phylogenetic relationships in Maloideae (Rosaceae): Evidence from sequences of the internal transcribed spacers of nuclear ribosomal DNA and its congruence with morphology. Amer. J. Bot. 82:903-918.

Charrier, B., F. Foucher, E. Kondorosi, Y. d'Aubenton-Carafa, C. Thermes, A. Kondorosi, and P. Ratet. 1999. Bigfoot: A new family of MITEelements characterized from the Medicago genus. Plant J. 18:431-441.

Cheng, F.S., N.F. Weeden, and S.K. Brown. 1996. Identification of co-dominant RAPD markers tightly linked to fruit skin color in apple. Theor. Appl. Genet. 93:222-227.

Federoff, N.V. 1989. Maize transposable elements, p. 375-411. In: D.E. Burge and M.M. Howe (eds.). Mobile DNA. Amer. Soc. Microbiol. Washington D.C.

Fisher, D.V. 1970. Spur strains of 'McIntosh' discovered in British Colombia, Canada. Fruit Var. Hort. Dig. 24:27-32.

Flavell, A.J., S.R. Pearce, and A. Kumar. 1994. Plant transposable elements and the genome. Curr. Opin. Genet. Devel. 4:838-844.

Kalendar, R., T. Grob, M, Regina, A. Suoniemi, and A. Schulman. 1999. IRAP and REMAP: Two new retrotransposon-based DNA fingerprinting 
techniques. Theor. Appl. Genet. 98:704-711.

Lapins, K. 1969. Segregation of compact growth types in certain apple seedling progenies. Can. J. Plant Sci. 49:765-768.

Mao, L., T.C. Wood, Y.Yu, M.A. Budiman, J. Tomkins, S. Woo, M. Sasinowski, G. Presting, D. Frisch, S. Goff, R.A. Dean, and R.A. Wing. 2000. Rice transposable elements: A survey of 73,000 sequence-tagged connectors. Genome Res. 10:982-990.

Phipps, J.B., K.R. Robertson, J.R. Rohrer, and P.G. Smith. 1991. Origins and evolution of subfamily Maloideae (Rosaceae). Systematic Botany 16:303-332.

Pozueta-Romero, J., G. Houlne, and R. Schantz. 1996. Nonautonomous inverted repeat alien transposable elements are associated with genes of both monocotyledonous and dicotyledonous plants. Gene 171:147-153.

Sambrook, J., E.F. Fritsch, and T. Maniatis. 1989. Molecular cloning, a laboratory manual, 2nd ed. Cold Spring Harbor Press. Cold Spring Harbor, N.Y.

Sax, K. 1931. The origins and relationships of the Pomoideae. J. Arnold Arbor. 12:3-22.

Song, W.Y., L.Y. Pi, T.E. Bureau, and P.C. Ronald. 1998. Identification and characterization of 14 transposon-like elements in the noncoding regions of members of the Xa21 family of disease resistance genes in rice. Mol. Gen. Genet. 258:449-456.

Stebbins, G.L. 1950. Variation and evolution in plants. Columbia Univ. Press, New York.

Varadarajan, G.S. and C.S. Prakash. 1991. A rapid and efficient method for the extraction of total DNA from the potato and its related species.
Plant Mol. Biol. Rep. 9:6-12.

Wessler, S.R. 1998. Transposable elements associated with normal plant genes. Physiol. Plant. 103:581-586.

Wessler, S.R., T.E. Bureau, and S.E. White. 1995. LTR-retrotransposons and MITEs: Important players in the evolution of plant genomes. Curr. Op. Genet. Dev. 5:814-821.

Westwood, M.N. 1993. Temperate-zone pomology: Species and varieties, 3rd ed. Timber Press, Portland, Ore.

Zhang, X., C. Feschotte, Q. Zhang, N. Jiang, W.B. Eggleston, and S.R. Wessler. 2001. P instability factor: An active maize transposon system associated with the amplification of tourist-like MITEs and a new superfamily of transposases. Proc. Natl. Acad. Sci. USA 98: 12572-12577. 